\title{
Chinese Health Assistance (CHA) in East Africa
}

\author{
Simon Ndwiga Gikiri ${ }^{1}$

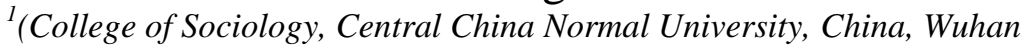

\begin{abstract}
This article reviews China's Health Assistance (CHA) within the East African Community (EAC) states. Such an analysis helps to identify the specific projects and activities undertaken within the broader knowledge body of China's Health Diplomacy and China's Health Assistance to Africa. Whereas there are contemporary challenges in the implementation of CHA projects in Africa, there is increasing positivity that strong diplomatic relations between China and member states in the EAC will strengthen these engagements. In building better understanding of CHA within the EAC, there is need to address the roles of the many actors involved in the provision of CHA in the EAC member states.

Keywords: China Chinese Health Assistance East Africa Community Health Diplomacy
\end{abstract}

\section{INTRODUCTION: AN OVERVIEW OF CHINA'S HEALTH ASSISTANCE}

Although there is increasing focus on Chinese engagements in Africa, particularly the issue of Aid and Health Assistance as a form of Aid by China is often discussed in generalities. Drawing from a wide source of publications, this article seeks to draw on specifics. The introductory section with provide an Overview of China's Health Assistance, describing it in its various forms.

Recent China - Africa scholarship has mostly focused on trade, industry, mineral extraction and energy. This focus ignores the health sector where China is also active (Brautigam, n. d; Wenjie, Wang, Cao and Jin 2014: 9; China's Foreign Aid Information Office of the State Council, People's Republic of China,2011; Brautigam, 2009). Nevertheless, medical assistance offered by the Chinese government also plays a significant role in China's foreign aid. Concerning the distribution of its development assistance, support to the health care sector seemingly, is an area where China has paid modest focus (Wenjie et al 2014:10)

Historically, it is in the year 1963 that China dispatched the first medical team to Algeria (David 2013:203). From 1963 to about the year 2009, the Chinese government has claimed to have sent 21000 medical workers on various missions abroad (ibid). China has sent medical teams to about 69 countries in Asia, Africa, Europe, Latin America, the Caribbean and Oceania. By the end of 2009, it is estimated that she had helped other countries of the developing world to build more than 100 hospitals and medical care centres, while at the same time provided them with a significant amount of medical equipment and medicines (Wenjie et al 2014:10).

Notably, many of the projects established in the medical sector are proportionally the smallest among all other areas of assistance. The history of China's Health Assistance (CHA) to health care sectors abroad is also comparatively shorter compared to the other areas of China's foreign aid (ibid); Lum et al. 2009: 9). Medical assistance is offered in various ways; it mainly includes the building of hospitals and medical care centres, the establishment of Malaria prevention and treatment centres, dispatching medical teams, training medical workers, and providing medicines and other medical materials.

Chinese Health Assistance (CHA) is perceived as having made many positive contributions to solving health problems where such assistance has been offered. Firstly, CHA has considerably improved in addressing the issue of health access which in the past was a significant barrier preventing people from getting medical service in most developing countries. Through CHA, there have been notable improvements in the existing medical care infrastructure as well as advances in the use of modern medical treatment technologies (ibid).

Secondly, we also find that in the recent past, China has continually strengthened exchanges and cooperation with developing countries mainly African states in the prevention and treatment of infectious diseases like AIDS and Malaria. Further engagements through $\mathrm{CHA}$ to the developing world and other nations has led to collaborations in the research and use of Traditional Chinese Medicines (TCMs-e.g. acupuncture, moxibustion, and therapeutic massage as noted by Jacob and Zhihao (2016). China has built about 30 Malaria prevention and treatment centres in African countries and has also provided artemisinin (an anti-Malaria treatment worth close to 190 million RMB (Jacob and Zhihao, 2016; Lum et al 2009:20).

In addition to the above, China is also involved in offering training to a large number of medical workers from other developing countries (South-South Training). The training and skills transfer is facilitated through Chinese Government Scholarships as well as practical training provided by Chinese medical teams dispatched abroad (Ashley 2013:332).

\section{Chinese Medical Teams (yiliaodui)}


As already mentioned, China sent the first medical team to an African state in 1963.Even before this time, China was already sending medical teams to different developing countries while at the same time providing free provisions like medical devices and medicines. Essentially, a Chinese medical team sent to a particular country provides location specific health services or at times provides mobile services in the host country. Such teams are often posted to work in difficult, underdeveloped areas where the health delivery systems are feeble, and the populace in such a location is in great need of medicines and health services (Brautigam 2009:33; Wenjie et al 2014:10). Estimates indicate that by the end of 2009, China had altogether sent over 21,000 medical workers to other countries, and these medical teams have treated 260 million patients in the host countries (Xiangheng and Sun 2014:1-2). In the same year, 60 Chinese medical teams consisting of 1,324 members were posted at 130 medical institutions in 57 developing countries.

\section{Emergency Humanitarian Aid}

China has also been involved in the provision of materials or cash needed for emergency relief. Depending on the situation, she also dispatches humanitarian personnel on her volition or at a request by a given state. China's active involvement in emergency relief operations in foreign countries has made her a valuable partner to the United Nations Agencies and other international organisations which play diverse roles in undertaking international emergency humanitarian assistance notes Lum et al (2009:3).

Overseas Volunteer Programs

China runs a volunteer program that sends volunteers to developing the world to serve the in the areas of education, medical and healthcare as well as in some social sectors (Wenjie et al 2014:11).

\section{Reasons for China's Medical Assistance to African Nations}

China has provided health assistance to Africa for over half a century, this being about 60 years (Xiangheng and Sun 2014:1-2). The start of official Chinese medical aid to Africa is pegged on the first dispatch of a medical team by China's government to Algeria in the January of 1963.The question of why is China engaged in the African Health sector is one that has elicited numerous responses. The motives for China to give health assistance to African states is based on varying historical contexts:

i. When official CHA was initiated, Chinese officials explained that medical aid to Africa was offered to improve the health of African people (Humanitarian concerns) as noted by Mathews (2013), The African Executive (2015), Pana Press (2015), Lucy (2013) and Wang and Sun 2014:1-2).

ii. Political Considerations. The political considerations are manifested in the timing and manner that China's decision to provide medical assistance to African nations was closely linked with the changing position that China has in international geopolitical space (Jiang, W. et al. (n. d); Lum et al 2009:5). Following the end of the Second World War and the formation of the United Nations after that, African nations had significant influence based on the principle of one country, one vote during voting of international organisations. As such, it was, and it is still important for China to establish and maintain close ties with African states so as to get their support. So as to ensure the support from African countries, provision of medical assistance was regarded as an effective strategy by the Chinese government.

With this regard, some of the other underlying political factors include;

a) The competition between the PRC and Taiwan to win the support of African states for a seat in the United Nations (Wenjie et al 2014:8),

b) Need for exerting international influence via diffusing the developmental ideologies of China's socialist experience and proletarian internationalism (Wang and Sun 2014:1-2),

iii. Economic Benefits: Economic benefits are also seen as a key motivation for China's involvement in the health sector in Africa, although the Chinese government has denied this suggestion. An argument is widespread that CHA in its various forms is used as a strategy to help China's state-owned enterprises to win market access and extract useful resources in Africa (H.E. SUN Shuzhong (2010); Wenjie et al 2014:9; Lum .et al. 2009:5; Wenjie et al 2014:11) but this claim has often been refuted by the Chinese government. 


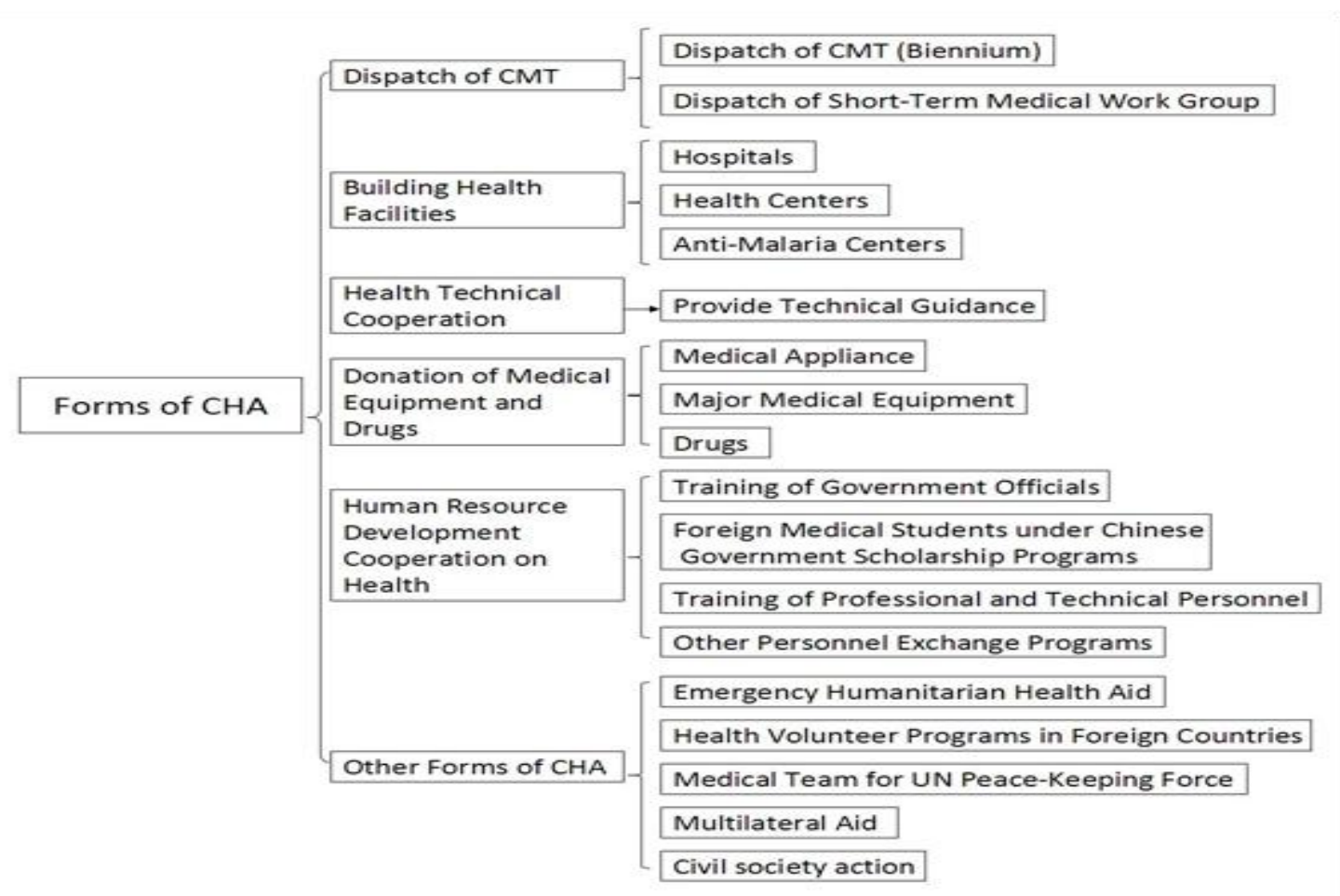

Fig 1. Forms of Chinese Health Assistance to the African States (Source: Liang et al, 2014).

\section{CHINESE HEALTH ASSISTANCE: ENGAGEMENTS IN EAST AFRICA}

This section will briefly highlight with examples, different forms of CHA in East African Community states of Rwanda, Tanzania, Burundi, Uganda, South Sudan and Kenya.

\section{Chinese Health Assistance in Kenya}

\section{(i)Hospital Construction and Upgrades}

The Mama Lucy Kibaki Hospital was built at the cost of KES550m (\$6.4M). The Government of Kenya provided the land on which the hospital is built and also provided additional finances for the construction of support works as well as the purchase of other equipment. Since the hospital commenced its operations, it is believed that it has served about 200,000 outpatients and up to 7,000 inpatients, besides having 3,000 deliveries to its credit (hospitalmanagement.net, March 2013).

This hospital also doubles up as one of the Malaria Treatment Centers funded by the Chinese Government(Ibid) Additionally, the Kenyatta University Teaching, Research and referral hospital is another landmark hospital construction project which has support from the Chinese government (Anyanzwa, June 2011). China has additionally provided support towards the building of a new wing at the Moi Teaching and referral hospital in Eldoret. The construction of the new 1,000-bed wing will increase the capacity of the hospital to 1,800 beds (Mathews, June 2013). Under this project, the Chinese government undertook works to put up a new in-patient complex. This further enhances the hospital's status as a referral teaching hospital while at the same time helps build the capacity of the hospital in serving a diversified clientele (ibid).

In the recent past, the Chinese government was responsible for providing funding to the tune of Kshs 380 million shillings for the upgrading of several district level hospitals namely:

Kakamega Hospital, Nyamira Hospital, Nyeri Hospital and Malindi Hospital. These hospitals are situated in the Western, Central and Coastal regions respectively (Pana Press, June 2015).

(iii)Medical Camps

The Chinese Navy hospital ship, the "Peace Ark" visited the port of Mombasa from October 13 to 18, 2010.The staff provided free health care services to Kenyan civilians and members of the armed forces. The primary services provided included: Diagnostic services and treatment for local citizens and students at Kenya Red Cross-Mombasa Branch, surgical operations aboard the ship for needy patients and physical examinations for Kenyan government officials, Kenya Navy Officers and Soldiers and Journalists.

The visit made by the Peace Ark was mainly to improve relations and cooperation between Kenya and China. Principal activities undertaken during this visit included the provision of Training and awards of donations. Training was offered to Kenyan medical personnel. Furthermore, they were offered an opportunity to take part in the diagnosis and treatment exercises aboard the Peace Ark (Mathews, June 2013; The African Executive, 2015). Medical officers aboard the ship also displayed a mix of nursing skills and Traditional Chinese Medicine 
treatment techniques such as acupuncture and cupping treatment. They later visited a local primary school and orphanage where they offered medical services to the children and taught them about healthcare (ibid).

iv. Donations and Training

Kenya does not get Chinese medical teams on a regular basis. Nonetheless, Chinese medical teams visiting Kenya often donate medicine, health supplies, stationery and other health consumable goods. Through the Chinese government scholarship program, many Kenyan health care workers travel and do their training in China. Similarly, there are specific institution-to-institution collaborations between Kenyan tertiary institutions and their Chinese counterparts. Comprehensive Malaria Prevention and Control Trainings have been conducted in Kenya by Chinese experts.

\begin{tabular}{|l|c|}
\hline \multicolumn{1}{|c|}{ Description } & Year \\
\hline Anti-tuberculosis drugs to the Kenyan Health Ministry (People's Daily,2002) & 2002 \\
\hline $\begin{array}{l}\text { Relief and Donations to the Kenya Red Cross Society (Embassy of the People's } \\
\text { Republic of China in the Republic of Kenya,2008; Permanent Mission of the } \\
\text { People's Republic of China to the UN Foreign Ministry Spokesperson Jiang } \\
\text { Yu's Remarks on the Situation in Kenya, 2008; Martin,2011) }\end{array}$ & $2004,2008,2011$ \\
\hline Donation to combat Rift Valley Fever (aiddata.org,2016) & 2007 \\
\hline $\begin{array}{l}\text { Donation for hunger victims (Embassy of the People's Republic of China in the } \\
\text { Republic of Kenya, 2011) }\end{array}$ & 2003 \\
\hline Donation of Anti-Malaria drugs (Donovan 2007:31; aiddata.org,2016) & 2003,2009 \\
\hline Donation of contraceptives and Medical equipment (Donovan 2007:31) & 12 \\
\hline Donations towards relief food (Xinhuanet and Guanqun,2011) & 2003,20 \\
\hline
\end{tabular}

Table 1: Key Medical Related Donations to Kenya by China (Source: Authors compilation)

\section{Chinese Health Assistance in Rwanda}

\section{i. Hospital Construction}

The Chinese Government has been involved in the Rwandese health sector since the 1980s, two district hospitals: Kibungo and Masaka have been built with funding from the Chinese government. The Masaka district hospital was completed in 2011 and is destined to be the Central Hospital of Rwanda (Paterne, n. d). Other projects which have involved the participation of the Chinese include a Polyclinic constructed in Masaka (Kagire, August 2009).

\section{ii.Chinese Medical Teams}

China started sending medical teams to Rwanda in 1982 (Xia, Wang, Duo-Quan, Jun, Qi, Salim, Chang-Sheng, Salim, Ya-Yi,Wei, Jia-Wen, Ying-Jun, Andrea, Robert, Tambo, Michael and Ning 2014:4 ) mostly drawn from Inner Mongolia. The post-genocide period saw a marked increase in the number of Chinese medical teams. In a period spanning three decades, medical teams from China have treated an estimated 470,000 patients either at Kibungo Hospital or in another closely linked programme aimed at the improvement of the health care facilities in the country (Paterne, n.d).

iii.Training the Health Care Force

Chinese medical teams continuously provide ongoing training for local medical workers. The teams rotate after every two years. The Chinese Government has also been offering many scholarships to Rwandan students in different fields, including health care (All Africa Global Media (allAfrica.com), August 2016)

iv.Medical Equipment \& Staffing

The Chinese government has been responsible for equipping hospitals where Chinese medical teams are based such as the District Hospital at Masaka and Kibungo (Paterne, n. d). Difficulties in running operations at the Kibungo Hospital without the Chinese team forced the Chinese embassy in Kigali to split the Chinese medical team into two; one team stationed in Masaka and the other in Kibungo. Other hospitals such as the Kinihira Hospital have also benefited from equipment and staff through the Chinese government (Babijja, 2013)

According to an interview done with Ambassador Zhan (All Africa Global Media (allAfrica.com), June 2013), Chinese doctors in Rwanda have worked very hard and treated about 47 thousand of local people in the past 30 years. Most of those who have benefited from medical services offered by the Chinese medical teams are victims of the Rwandan genocide, including some infected with HIV/AIDS. Additionally, the Chinese doctors have countless times worked under enormous pressure to carry out delicate surgeries in poorly equipped health centres in Rwanda.

iv.Donations 
A Malaria treatment centre at Kigukijo, set up in 2009 serves as an important recipient of antimalarial medicines (Xia et al, 2014). In 2013, the ministry of health in Rwanda acknowledged receipt of medical donations valued at USD 1,624,000 from China (Republic of Rwanda Ministry of Health, May 2013). Other donations were channeled to assist the quake victims in western part of the country that occurred in 2008 (Karuhanga, April 2008).

\section{Chinese Health Assistance in Tanzania}

The early 1970s are remembered as the focal times when the Chinese began the construction of the famous TanZam railway. This initial group of experts involved in the rail project also consisted of medical specialists (Jeremy 2010:151-2).

\section{i. $\quad$ Trainings}

Tanzania has benefited from China sending experts to offer training to its health workers through the Medical teams seconded from China and through annual scholarships provided to Tanzanians to study in China (Yuan. 2010:58-60). The Leah Amana Hospital has a Malaria treatment centre established in 2009 by the Chinese government. It is used to train Tanzanian health workers too (Xia et al 2014:17).

\section{ii. Donations}

Chinese medical teams have donated antimalarial drugs and medical equipment in facilities where they are stationed and in facilities where the team make visitations (Ministry of Foreign Affairs, the People's Republic of China, 2005). The Mnazi Mmoja General Hospital in Zanzibar has benefited from the presence of the Chinese medical team as well as equipment for the medical theatre while the Butiama District Hospital received donations of Malaria drugs.

Since 2008 to 2012, the Chinese government provides Malaria treatment drugs to the Tanzania health ministry to subsidise the cost of the medicines (Ibntv.com, 2013). Other donations from China have gone towards assisting those affected by the Tsunami that not only affected Tanzania but other nations along the coast of the Indian Ocean that occurred in 2005.

\section{iii. Medical teams}

Tanzania receives medical teams from the Chinese province of Shandong while the Jiangsu province primarily sent medical teams to Zanzibar Island (Hsu, n.d). These medical teams have worked in areas like Dodoma, Muhimbili, Tabora, Musoma, Ugunja and Pemba Islands.

\section{iv. Hospital Construction}

The Chinese government has supported a state of the art Cardiological unit, based within the Muhimbili hospital (Bilham, 2015). Muhimbili Hospital also doubles up as an important centre for Malaria treatment. Pharmaceutical manufacturing is another area of engagement where the Chinese are involved as noted by Brautigam (2011:2) and Mwilongo (2011:13); the Tanzansino United Pharmaceuticals Ltd is such an example. This firm produces drugs mostly for the treatment of infectious diseases.

\section{Chinese Health Assistance in Uganda}

\section{i. Hospital Construction}

The building of a Malaria treatment and prevention Centre at Mulago Hospital was completed in 2008 (Li, 2011) and stands out amongst hospital projects funded by the Chinese government as Mulago hospital is an important referral centre. Additionally, a China-Uganda Friendship Hospital in Naguru was also constructed with the support of the Chinese government (Ministry of Health Uganda, 2016).

\section{ii. Donations of Medical Equipment}

Uganda has received medical donations from China in the form of Antimalarial Drugs (Li,2011), received in different facilities like Mulago hospital, Jinja Hospital and the China-Uganda friendship hospital in Naguru; Donations of reproductive health medical equipment, computers and monetary donations have been sent to the Mulago Hospital (Edward 2013:115-117). Additionally, the Chinese government donated medical equipment to Uganda to boost its effort to promote reproductive health services (Xinhuanet, 2009; Brautigam 2011:2). Donations of medical hardware and laboratory supplies from the Chinese have also been sent to Uganda, primarily, a gift of medical laboratory equipment was shared between Mulago and Jinja hospitals (Steven, 2009; New Vision, 2009).

Grants for humanitarian relief have been seconded by the Chinese government, through the China Red Cross Society to the Government of Uganda (Serufusa, December 2013). Similarly, donations towards the containment of the Ebola Virus outbreak were received by the Ugandan government from the Chinese government (Obbo, May 2013).

\section{iii. Medical teams}

Uganda has for a long time since 1983 been receiving medical teams from China. The Yunnan Province has been responsible for sending the teams. The Medical teams that have arrived in Uganda have worked from the China-Uganda Friendship Hospital in Kampala while other teams have been received at the Jinja Hospital. 
China has also provided assistance to the reproductive health sector in Uganda primarily through sending experts on HIV/AIDS to assist in training and the donations of medical supplies (Eric 2009:35).

\section{Chinese Health Assistance in Burundi}

\section{i. Hospital construction}

China funded the construction of Mubangda General Hospital in 2008 and made a further commitment to equip the facility, supply antimalarial medications and deploy staff in the hospital. The hospital has since been renamed as the China-Burundi Friendship Hospital after the official inauguration. Other projects include the construction and equipping of a Malaria treatment centre in Bujumbura that was established in 2008 (Li 2011:14). The completion of the facility came with additional donations of Malaria drugs (ACT) donated by China (Republic of Burundi 2009:26). The Mpanda General Hospital has also benefited from Chinese assistance during its construction.

\section{ii. Donations, Training and Medical Teams}

Burundi has in the past received a donation of vehicles from China to its health ministry (Wang, 2012) together with hospital equipment and Anti-Malaria medications as highlighted above since the year 2005.Training of the health care force in Burundi is offered primarily through Postgraduate Scholarships provided by the Chinese government and through training and skills transfer done by the Chinese medical teams sent to Burundi ( $\mathrm{Li}, 2011: 11)$.

Initially, Burundi received medical teams from Guanxi, but the arrangement was changed towards the end of 1986 and the Qinghai province assumed the responsibility of sending medical teams to Burundi 1986(Ibid). Chinese Medical Teams sent to Burundi since 1987 have been dispatched in various hospitals in the country such as the Regional Hospital of Gitega, Prince Regent Charles Hospital, and the Mpanda General Hospital in Bubanza (AfricaXinhuanet.com, February 2016).

\section{Chinese Health Assistance in South Sudan}

Africa's youngest nation-the South Sudan joined the East Africa community block following a formal acceptance to accede to the East African community lately in the year 2016 and forged diplomatic relations with China in the year 2011.Despite a shorter history of China-South Sudan relations, a few developments are important to highlight about China's healthcare assistance to South Sudan.

\section{i. $\quad$ Hospital Construction}

The Bentiu -China Hospital was handed over to the government of South Sudan following its completion by the Chinese. This hospital offers both Chinese and Western medicine. Upgrades for the Kiir Mayardit Hospital in Rumbek, The Juba teaching hospital and Wau teaching hospital have received significant cash donations from the Chinese government too.

\section{ii. $\quad$ Medical Teams}

The arrival of medical teams in South Sudan dates back to the early 1970s. Medical teams from China have been working in the regions of Juba, Wau and Malakal. Prolonged conflict occasioned by the civil war in Sudan led to the discontinuation of medical teams to Sudan in 1985, but the exercise resumed later on in 2012 after China, and South Sudan signed a new memorandum of understanding on health assistance (Ullah 2015:187).

After its independence, South -Sudan received a medical team from the Anhui province at the Juba Teaching Hospital. The current Chinese Medical Teams in Wau and Juba offer not only treatment but also training to local medical staff and internships (Gong, June 2016; Guo, 2016). The Chinese medical team seconded to the Wau teaching hospital took responsibility for ensuring that most of the medical equipment and machines at the hospital were restored to functionality.

iii. Donations for Relief

The government of South Sudan has also received cash donations towards relief efforts which have been seconded mainly through the China Red Cross. China has also provided anti-Malarial medicines and committed to offering training of medical personnel based at the Rumbek hospital (Embassy of the People's Republic of China in South Sudan, 2011)

\section{CONCLUSION}

This article scales down the broader topic of China's Health Care assistance in Africa to a smaller region-the East Africa. A Health Diplomacy framework provides us with a tool to examine the nature of Chinese engagements in the health sectors within the East Africa region. In its simplest definition, health diplomacy covers the broad range of activities and discussions about how health is used as a means to improving international relations between nations (Kelley and Smith 2008:1-24; Katz, Kornblet, Lief, and Fischer 2009:505).

Specifically, in the context of this article, the use of health as a tool to improve international relations between China and the East African States. China's engagements within the health care sector in East Africa are likely to deepen beyond the current status. Several factors can be attributed to this projection; the strengthened 
diplomatic relations between China and the East African States, advances in communication, improvements in transport infrastructure, the deepening collaborations in research and education between China and East Africa coupled with increments in trade between China and these states (Ochieng, 2012).

There are stated commitments towards the improvements in standards of drugs produced by China, as well as initiatives to build production capacity of needed essential medicines. One of the strategies for improving the productive capacities of essential medicines is through the venturing of Chinese Pharmaceutical Companies in the East African health markets, the desired effect being that of meeting the current demand for cheap but essential medicines (ibid).

The East Africa Community states and China Chamber of Commerce for Import and Export of Medicines and Health Products (CCCMHPIE) has taken the lead towards the implementation of this strategy (China Chamber of Commerce for Import \& Export of Medicines \& Health Products (CCCMHPIE,2010). The forum has undertaken facilitations like workshops in which Chinese enterprises gather to explore potentials for expanding their activities (technology transfers, manufacturing and trade in medical consumables e.t.c) within the East African Community countries (Ochieng,2012).

Despite this positivity, the implementation of Chinese Health Assistance to Africa is not without challenges. Previously, disruptions to Chinese Health Assistance projects in East African have only been disrupted by conflicts (as was the case in South Sudan (Ullah 2015:187) and diplomatic issues with China (as was the case for Burundi and Kenya during the 1970s (Li 2011:9). Contemporary challenges faced on the implementation of Chinese health assistance to Africa include; Limited financing compared to other sectors of aid as previously highlighted, concerns on the efficacy of Traditional Chinese Medicine -an interest that pertains to the application of TCMs for the treatment of diseases which Chinese Medical Teams are perceived as being unfamiliar with (Xiangheng and Sun 2014:1-2).

Improvements in understanding the current and future roles assumed by China in health engagements in East Africa will need to address the many actors involved in the provision of CHA in the East African Community states. For example, examinations of the role of provincial governments, the role of private Chinese enterprises, the engagements of Chinese Non-Governmental Organisations (NGOs) and Government Organized Non-Governmental Organizations(GONGOs). Research reports are emerging on the participation of internationalising Chinese NGOs and GONGOs in the healthcare sector in Africa such as the China Foundation for Poverty Alleviation in hospital construction in Sudan and Humanitarian relief work.

\section{REFERENCES}

[1] D, Brautigam, "Chinese Development Aid in Africa: What, Where, Why, and How Much?” Accessed November 24, 2016.https://deborahbrautigam.files.wordpress.com/2013/04/2011-brautigam-chinese-aidin-africa.pdf.(1)

[2] L, Wenjie, W, Cao and N, Jin, “China's Approach in the Blooming South-South Health Cooperation: Chances, Challenges and the Way Forward (德国海德堡大学南南发展合作研讨会会议论文). Unpublished Work, 2014. (2)

[3] China's Foreign Aid Information Office of the State Council, People's Republic of China Beijing, "China's White Paper on Foreign Aid, April 2011. (3)

[4] D, Brautigam, “The Dragon's Gift the Real Story of China in Africa New York: Oxford University Press, 2009). (4)

[5] L, Wenjie, W, Cao and N, Jin, “China's Approach in the Blooming South-South Health Cooperation: Chances, Challenges and the Way Forward (德国海德堡大学南南发展合作研讨会会议论文).” Unpublished Work, 2014 (5)

[6] S, David, China Goes Global: The Partial Power (New York: Oxford University Press, 2013). (6)

[7] Ibid (7)

[8] L, Wenjie, W, Cao and N, Jin, "China's Approach in the Blooming South-South Health Cooperation: Chances, Challenges and the Way Forward (德国海德堡大学南南发展合作研讨会会议论文).” Unpublished Work, 2014 (8)

[9] Ibid (9)

[10] T, Lum, .et al, China's Foreign Aid Activities in Africa, Latin America and South East Asia.CRS Report for Congress, February 25, 2009 (10)

[11] Ibid (11)

[12] H, Jacob, and T, Zhihao, "TCM Touted for Big Role Internationally. Proc, Ninth Global Conf on Health Promotion, Shanghai 2016.In China Daily Thursday,” November 24, 2016. (12)

[13] Ibid (13)

[14] T, Lum, et al, China's Foreign Aid Activities in Africa, Latin America and South East Asia.CRS Report for Congress, February 25, 2009. (14) 
[15] J.T, Ashley, US-China Relations in a Realist World, In D.L. Shambaugh(Ed), Tangled Titans: The United States and China (Lanham: Rowman \& Littlefield, 2013).75-102 (15)

[16] D, Brautigam, "The Dragon's Gift the Real Story of China in Africa New York: Oxford University Press, 2009). (16)

[17] L, Wenjie, W, Cao and N, Jin, "China's Approach in the Blooming South-South Health Cooperation: Chances, Challenges and the Way Forward (德国海德堡大学南南发展合作研讨会会议论文).” Unpublished Work, 2014. (17)

[18] W, Xiangheng and Tao, S, China's Engagement in Global Health Governance: A Critical Analysis of China's Assistance to the Health Sector of Africa, Journal of Global Health, 4(1) (2014): 1-2 (18)

[19] T, Lum, .et al, China's Foreign Aid Activities in Africa, Latin America and South East Asia.CRS Report for Congress, February 25, 2009. (19)

[20] L, Wenjie, W, Cao and N, Jin, "China's Approach in the Blooming South-South Health Cooperation: Chances, Challenges and the Way Forward (德国海德堡大学南南发展合作研讨会会议论文), Unpublished Work, 2014. (20)

[21] W, Xiangheng and Tao, S, China's Engagement in Global Health Governance: A Critical Analysis of China's Assistance to the Health Sector of Africa, Journal of Global Health, 4(1) (2014): 1-2 (21)

[22] N, Mathews, Kenya: China to Fund SH7 Billion Moi Hospital New Wing, The Star Newspaper, 25 June 2013. http://allafrica.com/stories/201306251221.html.(22)

[23] The African Executive, Chinese Navy Hospital Ship Visits Kenya, 2015. http://www.africanexecutive.com/modules/magazine/articles.php?article=5505.(23)

[24] Pana Press, China to Build Hospital in Kenya, 25 June 2015. http://www.panapress.com/China-to-buildhospital-in-Kenya--13-521625-17-lang1-index.html.(24)

[25] C, Lucy, Why China Is Getting Involved in Africa's Health Issues,9 May 2013. http://edition.cnn.com/2013/05/09/opinion/china-africa-health/index.html.(25)

[26] W, Xiangheng and Tao, S, China's Engagement in Global Health Governance: A Critical Analysis of China's Assistance to the Health Sector of Africa, Journal of Global Health, 4(1) (2014): 1-2 (26)

[27] W, Jiang. et al, China's Approach in the Blooming South-South Health Cooperation: Chances, Challenges and the Way Forward, n.d (27)

[28] Lum, T.et al. "China's Foreign Aid Activities in Africa, Latin America and South East Asia.CRS Report for Congress," February 25, 2009. (28)

[29] L, Wenjie, W, Cao and N, Jin, "China's Approach in the Blooming South-South Health Cooperation: Chances, Challenges and the Way Forward (德国海德堡大学南南发展合作研讨会会议论文), Unpublished Work, 2014. (29)

[30] W, Xiangheng and Tao, S, China's Engagement in Global Health Governance: A Critical Analysis of China's Assistance to the Health Sector of Africa, Journal of Global Health, 4(1) (2014): 1-2 (30)

[31] H.E. Shuzhong Sun, China and Rwanda: New Era of Cooperation, Interview on $25^{\text {th }}$ November,2010, Retrieved from http://www.fmprc.gov.cn/zflt/eng/jlydh/sjzs/t772097.htm (31)

[32] L, Wenjie, W, Cao and N, Jin, "China's Approach in the Blooming South-South Health Cooperation: Chances, Challenges and the Way Forward (德国海德堡大学南南发展合作研讨会会议论文), Unpublished Work, 2014. (32)

[33] T, Lum, .et al, China's Foreign Aid Activities in Africa, Latin America and South East Asia.CRS Report for Congress, February 25, 2009 (33)

[34] hospitalmanagement.net, Kenya opens Mama Lucy Kibaki hospital. Retrieved from http://www.hospitalmanagement.net/news/newskenya-mama-lucy-kibaki-hospital-nairobi, March 2013. (34)

[35] Ibid (35)

[36] J, Anyanzwa, Sh10 billion to fund Kenyatta University's referral hospital, in the Standard Newspaper, June $18^{\text {th }}$ 2011, https://www.standardmedia.co.ke/article/2000037329/sh10-billion-to-fund-kenyattauniversity-s-referral-hospital (36)

[37] N, Mathews, Kenya: China to Fund SH7 Billion Moi Hospital New Wing.” The Star Newspaper, 25 June 2013. http://allafrica.com/stories/201306251221.html.(37)

[38] Ibid (38)

[39] Pana Press, China to Build Hospital in Kenya 25 June 2015. Accessed January 8, 2016 Retrieved from http://www.panapress.com/China-to-build-hospital-in-Kenya-13-521625-17-lang1-index.html.(39)

[40] N, Mathews, Kenya: China to Fund SH7 Billion Moi Hospital New Wing.” The Star Newspaper, 25 June 2013. Accessed January 12, 2016, Retrieved from http://allafrica.com/stories/201306251221.html.(40) 
[41] The African Executive, (2015). Chinese Navy Hospital Ship Visits Kenya. Retrieved from http://www.africanexecutive.com/modules/magazine/articles.php?article $=5505(41)$

[42] Ibid (42)

[43] Ibid (43)

[44] People's Daily, China Donates Anti-TB Medicine to Kenya." China Donates Anti-TB Medicine to Kenya, 2002. Retrieved from http://en.people.cn/200211/09/eng20021109_106534.shtml.(44)

[45] Embassy of the People's Republic of China in the Republic of Kenya, Donation to Kenya Red Cross Society by the Chinese Community in Kenya, 2008. Retrieved from Kenya http://ke.Chinaembassy.org/eng/xw/t396754.htm 2008/01/06(45)

[46] Permanent Mission of the People's Republic of China to the UN Foreign Ministry spokesperson Jiang $Y u$ 's Remarks on the Situation in Kenya 2008/01/18 (46)

[47] G, Martin, Huawei Donates Kshs 9.4 Million to the \#kenyans4kenya Initiative, 2011, Accessed January 12, 2016, Retrieved from http://www.techweez.com/2011/08/18/huawei-donates-kshs-9-4-million-to-thekenyans4kenya-initiativel.(47)

[48] aiddata.org, Rift Valley Fever Outbreak Relief, Accessed January 12, 2016, Retrieved from http://china.aiddata.org/projects/17744.(48)

[49] Embassy of the People's Republic of China in the Republic of Kenya, Chinese for Kenya-Relief Food to Turkana Program' Successfully Held, 2011, Retrieved from http://ke.Chinaembassy.org/eng/zfgx/t862905.htm.(49)

[50] C.C, Donovan, Political Warfare in Sub-Saharan Africa: U.S. Capabilities and Chinese Operations in Ethiopia, Kenya, Nigeria, and South Africa,2007 Retrieved from http://www.strategicstudiesinstitute.army.mil/pubs/display.cfm?pubID=766.(50)

[51] aiddata.org, China Donates Anti-Malaria Drugs to Kenya, Accessed January 12, 2016 Retrieved from http://China.aiddata.org/projects/1025http://China.aiddata.org/projects/1025 China Donates AntiMalaria Drugs to Kenya (51)

[52] C.C, Donovan, Political Warfare in Sub-Saharan Africa: U.S. Capabilities and Chinese Operations in Ethiopia, Kenya, Nigeria, and South Africa,2007 Retrieved from http://www.strategicstudiesinstitute.army.mil/pubs/display.cfm?pubID=766.(52)

[53] Xinhuanet and W, Guanqun, China Starts Delivering 20 Mln USD Food Aid to Kenya for Famine Relief," 2011. Retrieved from http://news.xinhuanet.com/english2010/China/201110/05/c_131175770.htm.(53)

[54] M, Paterne, The Friendship between China and Rwanda, Retrieved from http://rw.chineseembassy.org/eng/rdzt/P020120130634657315628.pdf, n.d (54)

[55] E, Kagire, Officials Commission China-Funded Hospital, August 5, 2009. Retrieved from http://www.newtimes.co.rw/section/Printer/2009-05-08/8387/.(55)

[56] X, Zhi-Gui, W, Ru-Bo, W, Duo-Quan, J, Feng, Q, Zheng, S, Abdulla, D, Chang-Sheng, G, Ya-Yi et al, China-Africa Cooperation Initiatives in Malaria Control and Elimination, 2014. Retrieved from http://www.repository.up.ac.za/dspace/bitstream/handle/2263/49699/Xia_China_2014.pdf?sequence=1 (56)

[57] M, Paterne, The Friendship between China and Rwanda, Retrieved from http://rw.chineseembassy.org/eng/rdzt/P020120130634657315628.pdf, n.d (57)

[58] All Africa Global Media (allAfrica.com, Rwanda: China Increases Education Sponsorship for Rwandan Students. All Africa Global Media (allAfrica.com). (58)

[59] Ibid (59)

[60] S, Babijja, Kinihira Hospital gets Chinese healthcare support, September 30, 2013, Accessed January 12, 2016, Retrieved from http://www.newtimes.co.rw/section/article/2013-09-30/69569/ (60)

[61] allafrica.com, Rwanda: African Ownership of Development (Interview Excerpts), Interview with Ambassador Shu Zhan's Discussion with Students from South California University and Stanford University on 27 June 2013. Retrieved from http://allafrica.com/stories/201306270905.html(61)

[62] X, Zhi-Gui, W, Ru-Bo, W, Duo-Quan, J, Feng, Q, Zheng, S, Abdulla, D, Chang-Sheng, G, Ya-Yi et al, China-Africa Cooperation Initiatives in Malaria Control and Elimination, 2014. Retrieved from http://www.repository.up.ac.za/dspace/bitstream/handle/2263/49699/Xia_China_2014.pdf? sequence=1.( 62)

[63] Republic of Rwanda Ministry of Health, Masaka hospital receives medical equipment worth USD 1,624,000, $8^{\text {th }}$ May 2013, Retrieved from http://www.moh.gov.rw/index.php?id=226 (63)

[64] J, Karuhanga. China donates \$50,000 to earthquake victims. April 12, 2008, in The New Times, Retrieved from http://www.newtimes.co.rw/section/article/2008-04-12/85939/ (64)

[65] Y, Jeremy, China's Health Diplomacy in Africa., China International Journal, 2010, 151-2 (65) 
[66] T, Yuan, China's Aid Logic to HRD in Tanzania: Give a Fish, Teaching to Fish, and Sharing the Fish., Network for International Policies and Cooperation in Education and Training., September 2010 Retrieved from http://www.norrag.org/es/publications/boletin-norrag/online-version/a-brave-new-worldof-emerging-non-dac-donors-and-their-differences-from-traditional-donors/detail/Chinas-aid-logic-tohrd-in-tanzania-give-a-fish-teaching-to-fish-and-sharing-the-fish.html, (58-60). (66)

[67] X, Zhi-Gui, W, Ru-Bo, W, Duo-Quan, J, Feng, Q, Zheng, S, Abdulla, D, Chang-Sheng, G, Ya-Yi et al, China-Africa Cooperation Initiatives in Malaria Control and Elimination, 2014. Retrieved from http://www.repository.up.ac.za/dspace/bitstream/handle/2263/49699/Xia_China_2014.pdf?sequence=1 (67)

[68] Ministry of Foreign Affairs, the People's Republic of China, China donates anti-malaria drugs to Tanzania, 05,11,2005, Retrieved from http://www.focac.org/eng/yhjl/t195169.htm (68)

[69] Ibntv.com, China boosts war against malaria.2013, Retrieved from http://www.ibntv.com/2013/08/China-boosts-war-against-malaria/. (69)

[70] E, Hsu, Medicine as business: Chinese medicine in Tanzania, Institute of Social \& Cultural Anthropology, University of Oxford, n.d(70)

[71] K, Bilham, Tanzania: First Ever Heart Institute Opens in Dar, September 2015, Retrieved from http://allafrica.com/stories/201509070394.html.(71)

[72] D, Brautigam, US and Chinese Efforts in Africa in Global health and foreign Aid Objectives, Impact, and Potential Conflicts of Interest, In X. L, Boynton and C. W, Freeman III(Eds), Chinas Emerging Global Health and Foreign Aid engagements in Africa. A report of the CSIS freeman Chair in China Studies and the CSIS Global Health Policy Center. November 2011. (72)

[73] J.S, Mwilongo, Challenges Perceived by Local Pharmaceutical Manufacturers That Hinder Adequate Production of Essential Medicines in Tanzania, Masters Dissertation, Muhimbili University of Health and Allied Sciences (MUHAS), July 2011. (73)

[74] A, Li, Chinese Medical Cooperation in Africa With Special Emphasis on the Medical Teams and AntiMalaria Campaign, 2011.Retrieved from https://nai.divaportal.org/smash/get/diva2:399727/FULLTEXT02. (74)

[75] Ministry of Health Uganda, China-Uganda Friendship Hospital Naguru, 2016. Retrieved from http://www.health.go.ug/sites/default/files/NaguruChina_Hospital.pdf.(75)

[76] A, Li, Chinese Medical Cooperation in Africa With Special Emphasis on the Medical Teams and AntiMalaria Campaign, 2011.Retrieved from https://nai.divaportal.org/smash/get/diva2:399727/FULLTEXT02. (76)

[77] K, Edward, Sino-Ugandan Relations: themes and issues, in S, Adem (Ed) China's diplomacy in Eastern and Southern Africa, (Farnham, Surrey: Ashgate, 2013). (77)

[78] Xinhuanet, China Donates Medical Equipment to Uganda, 2009, Retrieved from http://news.xinhuanet.com/english/2009-07/01/content_11629880.htm (78)

[79] D, Brautigam, US and Chinese Efforts in Africa in Global health and foreign Aid Objectives, Impact, and Potential Conflicts of Interest, In X. L, Boynton and C. W, Freeman III(Eds), Chinas Emerging Global Health and Foreign Aid engagements in Africa. A report of the CSIS freeman Chair in China Studies and the CSIS Global Health Policy Center. November 2011. (79)

[80] C, Steven, Uganda: Mulago, Jinja Hospitals Get Laboratory Equipment in New Vision, 2009.retrieved from http://allafrica.com/stories/200907060552.html.(80)

[81] New Vision, 2009, Mulago, Jinja Hospitals Get Laboratory Equipment. Retrieved from http://www.newvision.co.ug/new_vision/news/1241014/mulago-jinja-hospitals-laboratory-equipment.(81)

[82] S, Serufusa, China's Aid to Uganda's Health Sector in Gobalhealthhub.org, December 2, 2013, Retrieved from http://www.globalhealthhub.org/2013/12/02/chinas-aid-to-ugandas-health-sector/.(82)

[83] C. O, Obbo, Uganda-Is-Still-the-Same-Beggar-Is-China-a-Different, May 8, 2013. Retrieved from http://www.monitor.co.ug/OpEd/columnists/CharlesOnyangoObbo/Uganda-is-still-the-same-beggar--isChina-a-different-/878504-1845278-my9dod/index.html.(83)

[84] L, Eric, Chinas Smart Power in Reproductive Health: Reaching out to Uganda, In C, McGiffert (Ed) Chinese Soft Power and Its Implications for the United States: Competition and Cooperation in the Developing World: A Report of the CSIS Smart Power Initiative, CSIS, 2009. (84)

[85] A, Li, Chinese Medical Cooperation in Africa With Special Emphasis on the Medical Teams and AntiMalaria Campaign, Nordiska Afrika Institutet, Uppsala 2011. Retrieved from https://nai.divaportal.org/smash/get/diva2:399727/FULLTEXT02. (85)

[86] Republic of Burundi, Support the Achievement of Universal Long-Lasting Insecticide Treated Mosquito nets (LLITN) for Sustainable Malaria Prevention in Burundi, June 2009.A funding proposal submitted to the Global Fund. (86) 
[87] Y, Wang, China Donates Vehicles to Burundi's Health Ministry, in Xinhua, 2012. Retrieved from http://www.gov.cn/misc/2012-04/24/content_2122097.htm.(87)

[88] A, Li, Chinese Medical Cooperation in Africa With Special Emphasis on the Medical Teams and AntiMalaria Campaign, Nordiska Afrika Institutet, Uppsala 2011. Retrieved from https://nai.divaportal.org/smash/get/diva2:399727/FULLTEXT02 (88)

[89] Ibid (89)

[90] AfricaXinhuanet.com, Burundi welcomes 16th mission of Chinese medical experts. February 12, 2016, Retrieved from http://news.xinhuanet.com/english/africa/2014-06/07/c_133389375.htm 2014-06-07. 2014-06-07. (90)

[91] K, M, Ullah, Relations, China-Africa Economic Relations: China-Africa, Africa Economic Forum, 2015. (91)

[92] Y, Gong, Ancient Cures for a New Nation, in China Daily Africa, June 17, 2016. Retrieved from http://africa.chinadaily.com.cn/2016-06/17/content_25751578.htm.(92)

[93] J, Guo, Chinese Medical Team in South Sudan Ten Years on, in CRIENGLISH.com, 2016. Retrieved from http://english.cri.cn/12394/2016/01/02/2743s911120.htm.(93)

[94] Embassy of the People's Republic of China in South Sudan, China Donated Anti-Malarial Drugs to South Sudan, December 01, Retrieved from http://ss.chineseembassy.org/eng/sbjw/t883134.htm.(94)

[95] L, Wenjie, W, Cao and N, Jin, "China's Approach in the Blooming South-South Health Cooperation: Chances, Challenges and the Way Forward (德国海德堡大学南南发展合作研讨会会议论文), Unpublished Work, 2014. (95)

[96] Ibid (96)

[97] Lee, Kelley, and Richard Smith. "What is 'Global Health Diplomacy'? A Conceptual Review” 44, no. 0 (2008): 1-24. (97)

[98] R, Katz, S, Kornblet, G, Arnold, E, Lief, and J.E. Fischer, Defining Health Diplomacy: Changing Demands in the Era of Globalization, The Milbank Quarterly. A Multidisciplinary Journal of Population Health and Health Policy 87 (4)2009, 842-62. doi:10.1111/j.1468-0009.2010.00608. x. (98)

[99] B,Ochieng, Africa Focus: Kenya hails China's assistance in health sector [Internet]. xinhuanet.com. 2012. Retrieved from http://news.xinhuanet.com/english/world/2012-09/14/c_123713687.htm. (99)

[100] Ibid (100)

[101] China Chamber of Commerce for Import \& Export of Medicines \& Health Products (CCCMHPIE), About CCCMHPIE (Official Website)2010, Retrieved from http://www.cccmhpie.org.cn/English/EShowListAll.aspx.(101)

[102] B, Ochieng, Africa Focus: Kenya hails China's assistance in health sector [Internet]. xinhuanet.com. 2012. Retrieved from: http://news.xinhuanet.com/english/world/2012-09/14/c_123713687.htm (102)

[103] K, M, Ullah, Relations, China-Africa Economic Relations: China-Africa, Africa Economic Forum, 2015. (103)

[104] A, Li. 'Chinese Medical Cooperation in Africa With Special Emphasis on the Medical Teams and AntiMalaria Campaign'. Nordiska Afrika Institutet, Uppsala 2011. Retrieved from https://nai.divaportal.org/smash/get/diva2:399727/FULLTEXT02.(104)

[105] W, Xiangheng and Tao, S, China's Engagement in Global Health Governance: A Critical Analysis of China's Assistance to the Health Sector of Africa, Journal of Global Health, 4(1) (2014): 1-2. (105) 